\title{
Circulating Tumor Cell Count
}

National Cancer Institute

\section{Source}

National Cancer Institute. Circulating Tumor Cell Count. NCI Thesaurus. Code C96593.

The determination of the amount of circulating tumor cells present in a sample. 